2. Glushenko, T.M. (2014). Analiz rozvutky logistuchnuh poslyg na sychasnomy svitovomy runky [Analysis of the development of logistics services in the modern world market]. Naykovui visnuk Chersonskogo derjavnogo yniversutety - Scientific Herald of Kherson State University, 6, 169-171. [In Ukrainian].

3. Dovba M.O. Aytsorsung na runky logistuchnuh poslyg: perspektuvu v Ukraini. [Outsourcing in the market of logistics services: prospects in Ukraine]. (n.d.). file:///C:/Users/danul/Downloads/Nzlubp_2011_7_20.pdf. [In Ukrainian].

4. Zavgorodniy, K.V. (2016). Stanovlennia logistuchnogo aytsorsingy yak instrymenty ypravlinniy regionalnumu transformaciiymu [Development of logistics outsourcing as a tool for managing regional transformations]. Naykovui visnuk Chersonskogo derjavnogo yniversutety - Scientific Herald of Kherson State University, 21, 96-99. [In Ukrainian].

5. Krasnoshapka, V.V. \& Trohumets, I.I. (2015). Aytsorsung ta jogo zastosyvannia na pidpruiemstvah Ukrainu [Outsourcing and its use at Ukrainian enterprises]. Efektuvna ekonomika - Effective economy, 5. (n.d.). http://www.economy.nayka.com.ua Retrieved from http://www.economy.nayka.com.ua/?op=1\&z=4097 [In Ukrainian].

6. Logistuka yak instryment optumizatsii biznes-protsesiv ta napryam naykovogo piznannya. [Logistics as a tool for optimizing business processes and the direction of scientific knowledge]. (n.d.). https://pidruchniki.com/71570/logistika/logistika_instrument_optimizatsiyi_biznes-

protsesiv_napryam_naukovogo_piznannya. [In Ukrainian].

7. Logistuchnui aytsorsing. [Logistics outsourcing]. (n.d.). https://tsl.kname.edu.ua/index.php/en/8-glavnaya/26logistic-outsourcing. [In Ukrainian].

8. Osnovni tendentsii zastosyvannya aytsorsingy na runky logistuchnuh poslyg $\mathrm{v}$ Ykraini. [The main tendencies of outsourcing use in the market of logistic services in Ukraine]. (n.d.). http://calculino.info/ru/usefull/articles/id208457. [In Ukrainian].

9. Tishchenko, O. M. (2012). Autsorsing yak factor efektuvnosti pidpruyemstv bydivelnoi galyzi [Outsourcing as a factor in the efficiency of the construction industry]. Problemu ekonomiku-Problems of the economy, 4, 129-135. [In Ukrainian].

10.2019 third-party logistics study: The State of Logistics Outsourcing. (n.d.). https://dsqapj1lakrkc.cloudfront.net/media/sidebar_downloads/2019-3PL-Study.pdf. [United States of America].

11. Percentage of 3PL users who outsource logistics services as of 2018, ranked by the most frequently outsourced services. (n.d.). https://www.statista.com/statistics/660142/transportation-and-logistics-mostoutsourced-services/.[United States of America].

12. Langley, $\quad$ J. $\quad$ Third-Party Logistics Study - $\quad 2018 . \quad$ (n.d.). https://mymaritimeblog.files.wordpress.com/2017/10/3pl_2018_study.pdf. [United States of America].

Стаття надійшла до редакції 24.06.2019 р.

УДК 378.245:004.4

Павліха Наталія, доктор економічних наук, професор, проректор 3 науково-педагогічної роботи та міжнародних зв'язків, Східноєвропейський національний університет імені Лесі Українки, м. Луцьк; ORCID ID 0000-0001-5191-242X e-mail: pavlixa2@gmail.com

Тоцька Олеся, кандидат економічних наук, доцент, Східноєвропейський національний університет імені Лесі Українки, кафедра менеджменту; м. Луцьк; ORCID ID 0000-0003-4748-2134 e-mail: o_totska@meta.ua 
https://doi.org/10.29038/2411-4014-2019-03-62-71

\section{ПЛАНУВАННЯ ПРОЕКТУ ПІДГОТОВКИ ДОКТОРА НАУК ЗАСОБАМИ МICROSOFT OFFICE PROJECT}

У статті розглянуто підготовку доктора наук як науковий проект. Зазначено його характерні ознаки. Віднесено до певних видів проектів за різними класифікаційними ознаками. Перелічено характеристики проекту. Конкретизовано процеси, пов'язані з проектом, які реалізують різні функції управління. Здійснено планування проекту підготовки доктора наук засобами Microsoft Office Project. Перераховано його задачі, визначено необхідні ресурси. Універсальність розробленого проекту полягає в тому, що його можна застосовувати в діяльності відділу докторантури будь якого закладу вищої освіти (наукової установи) України для підвищення ефективності управління підготовкою докторів наук.

Ключові слова: науковий проект, підготовка доктора наук, планування, ресурси, Microsoft Office Project.

Павлиха Наталья,

доктор экономических наук, профессор, проректор по научно-педагогической работе и международным связям, Восточноевропейский национальный университет имени Леси Украинки, г. Луцк

Тоцкая Олеся, кандидат экономических наук, доцент, Восточноевропейский национальный университет имени Леси Украинки, кафедра менеджмента, г. Луцк

\section{ПЛАНИРОВАНИЕ ПРОЕКТА ПОДГОТОВКИ ДОКТОРА НАУК СРЕДСТВАМИ МICROSOFT OFFICE PROJECT}

В статье рассмотрено подготовку доктора наук как научный проект. Указано его характерные признаки. Отнесено к определенным видам проектов по различным классификационным признакам. Перечислены характеристики проекта. Конкретизированы процессы, связанные с проектом, которые реализуют различные функции управления. Осуществлено планирование проекта подготовки доктора наук средствами Microsoft Office Project. Перечислено его задачи, определено необходимые ресурсы. Универсальность разработанного проекта заключается в том, что его можно применять в деятельности отдела докторантуры любого учреждения высшего образования (научного учреждения) Украины для повышения эффективности управления подготовкой докторов наук.

Ключевые слова: научный проект, подготовка доктора наук, планирование, pecyрсы, Microsoft Office Project.

Pavlikha Nataliia, Doctor of Economics, Professor,

Vice-Rector for Scientific and Pedagogical Work and International Relations, Lesya Ukrainka Eastern European National University, Lutsk

Totska Olesia,

PhD in Economics, Associate Professor, Lesya Ukrainka Eastern European National University, Department of Management, Lutsk

\section{PLANNING OF THE DOCTOR OF SCIENCES TRAINING PROJECT BY MICROSOFT OFFICE PROJECT}

The article deals with the preparation of the doctor of sciences as a scientific project. The main indicators of doctoral students' activity in Ukraine for the last nine years are presented. A brief review of domestic literary sources devoted to separate aspects of scientific projects was conducted. The characteristic features of the project of preparation of the doctor of sciences (purpose, available hierarchical goals, coordinated implementation of related actions, time frame, availability of budget, uniqueness) are indicated. Included in certain types of projects according to different classification features (scale / size, duration / terms of implementation, industry affiliation, functional 
orientation, nature of the involved parties, degree of complexity, composition and structure of the involved organizations, requirements to project quality, degree of binding, degree of connection, number of participants). The characteristics of the project (goal, vision and strategy, commercial benefits, organizational changes, time and costs) are listed. The processes associated with the project, which implement various management functions (initiation, planning, execution, monitoring and management, completion), are specified. The project of preparation of the doctor of sciences with Microsoft Office Project is planned. The budget and time limits of the project are indicated. For each project task the following information is provided: the number of the line in the project, the number in the structural decomposition of the work, the name, the cost of its implementation, the duration, the dates of beginning and end, the numbers of strings of predecessor tasks, the names of resources assigned to it, indicating the units or costs. The versatility of the developed project is that it can be applied to the work of the doctoral department of any institution of higher education (scientific institution) of Ukraine for the management of the preparation of doctors of sciences with outgoing changes in the duration of tasks, dates of their beginning and ending and the costs of their implementation. The draft project of preparation of the doctor of sciences can also serve as the basis for other scientific projects.

Keywords: scientific project, preparation of the doctor of sciences, planning, resources, Microsoft Office Project.

Постановка проблеми. На нашу думку, підготовку доктора наук у докторантурі закладу вищої освіти (наукової установи) України можна розглядати як науковий проект. Адже в процесі такої підготовки виконується низка задач, де час і ресурси - обмежені. А, згідно визначення, проект - це сукупність цілеспрямованих, послідовно орієнтованих у часі, одноразових, комплексних i нерегулярно повторюваних дій (заходів або робіт), орієнтованих на досягнення кінцевого результату в умовах заданості термінів їх початку та завершення, а також обмеження трудових, матеріальних i фінансових ресурсів [1, с. 9].

У зв'язку з тим, що в останні дев'ять років частка осіб, які закінчили докторантуру із захистом дисертації не перевищувала 33,3 \% (табл. 1), виникає потреба пошуку нових шляхів підвищення ефективності управління процесом їх підготовки.

Таблицุя 1

Основні показники діяльності докторантури в Україні

\begin{tabular}{|l|r|r|r|r|r|r|r|r|r|}
\hline \multicolumn{1}{|c|}{ Показник } & $\mathbf{2 0 1 0}$ & $\mathbf{2 0 1 1}$ & $\mathbf{2 0 1 2}$ & $\mathbf{2 0 1 3}$ & $\mathbf{2 0 1 4}$ & $\mathbf{2 0 1 5}$ & $\mathbf{2 0 1 6}$ & $\mathbf{2 0 1 7}$ & $\mathbf{2 0 1 8}$ \\
\hline $\begin{array}{l}\text { Кількість осіб, які закінчили } \\
\text { докторантуру, за рік }\end{array}$ & 450 & 483 & 418 & 566 & 524 & 563 & 551 & 543 & 963 \\
\hline $\begin{array}{l}\text { у тому числі із захистом } \\
\text { дисертації } \\
\text { осіб }\end{array}$ & 130 & 125 & 139 & 187 & 143 & 169 & 153 & 153 & 232 \\
\hline відсотків & 28,9 & 25,9 & 33,3 & 33,0 & 27,3 & 30,0 & 27,8 & 28,2 & 24,1 \\
\hline \multicolumn{1}{|l}{ Джерело: [2] }
\end{tabular}

Тут на допомогу може прийти теорія управління проектами та різноманітні засоби автоматизації такого процесу, зокрема комп’ютерна програма Microsoft Office Project.

Аналіз досліджень і публікацій. Питання підготовки докторів наук у закладах вищої освіти розглянуто вченими в наукових працях, присвячених розкриттю особливостей здійснення освітнього менеджменту. Зокрема, у таких роботах, як [3-4] обгрунтовано пропозиції щодо підвищення ефективності управління процесами надання освітніх послуг в регіонах України. 3 точки зору управління проектами в освітній сфері зазначимо, що вітчизняними науковцями розкрито сутність освітніх і наукових проектів. Так, Д. І. Бедрій здійснив аналіз експертного методу оцінки ризиків наукових проектів [5], Д. І. Бедрій та І. В. Польшаков - бюджетування наукових проектів 3 урахуванням ризиків [6]. Водночас С. Г. Головко досліджувала досвід і перспективи європейського виміру докторської підготовки у вітчизняній вищій школі [7]. Як бачимо, в цих публікаціях підготовка доктора наук не розглядалась як науковий проект i, відповідно, не використовувались автоматизовані засоби управління проектами.

Постановка завдання. Метою статті $\epsilon$ теоретико-методичне обгрунтування процесу планування проекту підготовки доктора наук засобами Microsoft Office Project. Для ïi peалізації поставлено та виконано такі завдання:

- розглянути підготовку доктора наук як науковий проект;

- розробити проект підготовки доктора наук засобами Microsoft Office Project. 
Виклад основного матеріалу. Характерними ознаками як освітнього, так і наукового проекту підготовки доктора наук є:

1) мета - захист у постійно діючій спеціалізованій вченій раді результатів власних наукових досягнень у вигляді дисертації або опублікованої монографії, або наукової доповіді за сукупністю статей, опублікованих у вітчизняних і міжнародних рецензованих фахових виданнях, перелік яких затверджується МOH;

2) наявні ієрархічні цілі - підготовка та публікація тез доповідей і наукових статей, написання окремих підрозділів дисертації, міжсеместровий і річний звіт, попередній захист дисертації на кафедрі;

3) координоване виконання пов'язаних між собою дій - наукове дослідження проводиться згідно з індивідуальним планом наукової роботи;

4) часові рамки - два роки (нормативний строк підготовки доктора наук у докторантурі) [8];

5) наявність бюджету - покриття витрат на публікацію тез доповідей, наукових статей, оголошення про захист дисертації, поліграфічні послуги, розсилання авторефератів, а також транспортних витрат (на доїзд до / з спеціалізованої вченої ради) може відбуватися за рахунок академічної стипендії. Докторантам, які навчаються за денною формою (з відривом від виробництва), вона встановлюється в розмірі 90 \% посадового окладу професора [9];

6) унікальність - у дисертації, підготовленій здобувачем ступеня доктора наук, буде представлене узагальнення проведених самостійно оригінальних досліджень 3 отриманими науковими результатами, які забезпечують розв'язання важливої теоретичної або прикладної проблеми, мають загальнонаціональне або світове значення.

За різними класифікаційними ознаками науковий проект підготовки доктора наук у докторантурі віднесемо до таких видів проектів:

1) за масштабом / розміром (малі; середні; великі) - малий;

2) за тривалістю / строками реалізації (короткострокові (до 3 років); середньострокові (від 3 до 5 років); довгострокові (понад 5 років)) - короткостроковий;

3) за галузевою приналежністю (промислові; будівельні; транспортні; освітні; у сфері торгівлі; комплексні тощо) - науковий;

4) за функціональним спрямуванням (виробничі; технологічні; фінансові; дослідження та розвитку; маркетингові; з управління персоналу; комбіновані) - дослідження та розвитку;

5) за характером залучених сторін (міжнародні; національні; територіальні; місцеві) - місцевий;

6) за ступенем складності (прості; складні; дуже складні (комплексні)) - складний;

7) за складом і структурою залучених організацій (однофункціональні; багатофункціональні) однофункціональний;

8) за вимогами до якості проекту (стандартні; з надзвичайними вимогами) - стандартний;

9) за ступенем обов'язковості (обов'язкові; необов'язкові) - обов'язковий;

10) за ступенем зв'язку (альтернативні; незалежні; взаємопов'язані) - незалежний;

11) за кількістю учасників (індивідуальні, групові та колективні) - індивідуальний.

Характеристиками проекту підготовки доктора наук, які відрізняють його від програми чи портфеля проектів, $\epsilon$ :

а) ціль - захищені в постійно діючій спеціалізованій вченій раді результати власних наукових досягнень у вигляді дисертації або опублікованої монографії, або наукової доповіді за сукупністю статей, опублікованих у вітчизняних і міжнародних рецензованих фахових виданнях, перелік яких затверджується МOH;

б) бачення та стратегія - взаємозв'язані через індивідуальний план наукової роботи;

в) комерційна вигода - відсутня;

г) організаційні зміни - виключені;

д) час, витрати - два роки; витрати залежать від вартості запланованих наукових публікацій і ін.

У проекті підготовки доктора наук наявні такі п’ять основних груп процесів, які реалізують різні функції управління:

1) ініціації - зарахування до докторантури;

2) планування - визначення змісту, строків виконання й обсягу наукових робіт, а також запланованого строку захисту дисертації протягом строку підготовки в докторантурі; 
3) виконання - виконання докторантом індивідуального плану наукової роботи;

4) моніторингу й управління - консультування докторанта щодо змісту та методології наукових досліджень, контроль виконання його індивідуального плану наукової роботи;

5) процеси завершення - захист результатів власних наукових досягнень у постійно діючій спеціалізованій вченій раді.

За нашими приблизними розрахунками бюджет проекту підготовки доктора наук складає 12250 грн. Часові межі проекту становлять 301.10 .2018 р. до 30.09 .2020 p. Неробочими днями в проекті є суботи, неділі, а також святкові дні, які припадають на цей період. Фрагмент форми «Діаграма Ганта» проекту в програмі Microsoft Office Project подано на рис. 1.

Перелік задач проекту сформовано на основі інформації 3 [8] та відображено в табл. 1-2. Фактично ці таблиці є лівою частиною форми «Діаграма Ганта» програми Microsoft Office Project. У ній для кожної задачі подано таку інформацію: номер рядка в проекті, номер у структурній декомпозиції робіт (СДР), назву, витрати на іï реалізацію, тривалість, дати початку та закінчення, номери рядків задач-попередників, назви призначених їй ресурсів із зазначенням одиниць (у \%) або витрат (у грн).

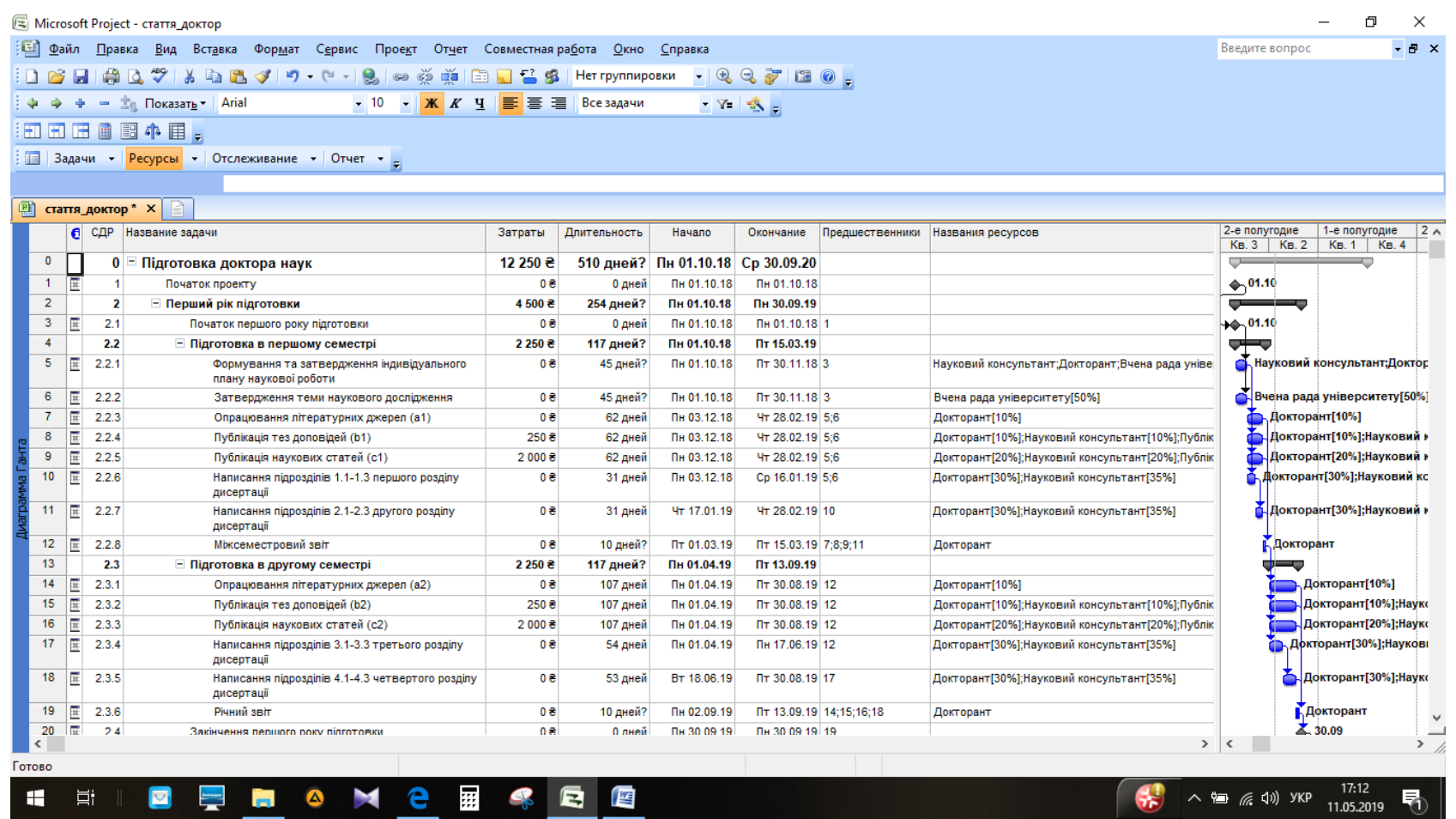

Рис. 1. Фрагмент форми «Діаграма Ганта» проекту підготовки доктора наук

Джерело: сформовано авторами.

Згідно проекту, підготовка доктора наук у перший рік займе 254 дні та коштуватиме 4500 грн. Протягом цього періоду докторант повинен опрацювати літературні джерела, підготувати низку тез і статей, написати чотири розділи дисертації.

Згідно проекту, підготовка доктора наук у другий рік триватиме 255 днів і коштуватиме 7750 грн. Протягом цього періоду докторант також повинен опрацювати літературні джерела, підготувати низку тез і статей, окрім того написати один розділ дисертації, а також пройти попередній захист результатів власних наукових досягнень на кафедрі та подати до спеціалізованої вченої ради результати власних наукових досягнень.

Як бачимо, в табл. 1-2 для деяких задач, як от публікація тез доповідей і наукових статей, написання конкретних підрозділів дисертації, окрім докторанта в якості ресурсу зазначався також науковий консультант, оскільки він повинен здійснювати керівництво цими роботами, а також може бути співавтором публікацій. 
Таблиияя 1

Задачі проекту підготовки доктора наук протягом першого року

\begin{tabular}{|c|c|c|c|c|c|c|c|c|}
\hline $\begin{array}{l}\text { № } \\
\text { ряд } \\
\text { ка }\end{array}$ & СДР & Назва задачі & $\begin{array}{l}\text { Витра- } \\
\text { ти, } \\
\text { грн }\end{array}$ & $\begin{array}{l}\text { Три- } \\
\text { ва- } \\
\text { лість, } \\
\text { днів }\end{array}$ & Початок & $\begin{array}{l}\text { Закінче- } \\
\text { ння }\end{array}$ & $\begin{array}{l}\text { По- } \\
\text { пе- } \\
\text { ред- } \\
\text { ни- } \\
\text { ки } \\
\end{array}$ & $\begin{array}{l}\text { Назви } \\
\text { ресурсів }\end{array}$ \\
\hline 1 & 2 & 3 & 4 & 5 & 6 & 7 & 8 & 9 \\
\hline 0 & 0 & Підготовка доктора наук & $\begin{array}{l}1225 \\
0\end{array}$ & 510 & Пн 01.10.18 & $\begin{array}{l}\mathrm{Cp} \\
30.09 .20\end{array}$ & & \\
\hline 1 & 1 & Початок проекту & 0 & 0 & Пн 01.10 .18 & $\begin{array}{l}\Pi_{\mathrm{H}} \\
01.10 .18\end{array}$ & & \\
\hline 2 & 2 & Перший рік підготовки & 4500 & 254 & Пн 01.10 .18 & $\begin{array}{l}\Pi_{\mathrm{H}} \\
30.09 .19\end{array}$ & & \\
\hline 3 & 2.1 & 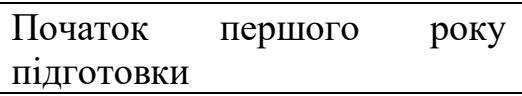 & 0 & 0 & Пн 01.10 .18 & $\begin{array}{l}\Pi_{\mathrm{H}} \\
01.10 .18\end{array}$ & 1 & \\
\hline 4 & 2.2 & $\begin{array}{lll}\begin{array}{l}\text { Підготовка } \\
\text { семестрі }\end{array} & \text { в } & \text { першому } \\
\end{array}$ & 2250 & 117 & Пн 01.10.18 & $\begin{array}{l}\Pi_{\mathrm{T}} \\
15.03 .19\end{array}$ & & \\
\hline 5 & 2.2 .1 & $\begin{array}{l}\text { Формування та затвердження } \\
\text { індивідуального } \\
\text { наукової роботи }\end{array}$ & 0 & 45 & Пн 01.10 .18 & $\begin{array}{l}\text { Пт } \\
30.11 .18\end{array}$ & 3 & $\begin{array}{l}\text { НК;Д;В } \\
\text { РУ[50 } \\
\%]\end{array}$ \\
\hline 6 & 2.2 .2 & $\begin{array}{l}\text { Затвердження теми наукового } \\
\text { дослідження }\end{array}$ & 0 & 45 & Пн 01.10.18 & $\begin{array}{l}\text { Пт } \\
30.11 .18\end{array}$ & 3 & $\begin{array}{l}\text { BPУ }[50 \\
\%]\end{array}$ \\
\hline 7 & 2.2 .3 & $\begin{array}{l}\text { Опрацювання } \\
\text { джерел (a1) }\end{array}$ & 0 & 62 & Пн 03.12.18 & $\begin{array}{l}\text { Чт } \\
28.02 .19\end{array}$ & $5 ; 6$ & Д[10\%] \\
\hline 8 & 2.2 .4 & Публікація тез доповідей (b1) & 250 & 62 & Пн 03.12.18 & $\begin{array}{l}\text { Чт } \\
28.02 .19\end{array}$ & $5 ; 6$ & $\begin{array}{l}\text { Д[10\%] } \\
; Н К[10 \\
\%] ; П Т[~ \\
\text { 250Z] }\end{array}$ \\
\hline 9 & 2.2 .5 & $\begin{array}{l}\text { Публікація наукових статей } \\
\text { (c1) }\end{array}$ & 2000 & 62 & Пн 03.12.18 & $\begin{array}{l}\text { Чт } \\
28.02 .19\end{array}$ & $5 ; 6$ & $\begin{array}{l}\text { Д[20\%] } \\
; Н К[20 \\
\%] ; П С[ \\
2000 Z]\end{array}$ \\
\hline 10 & 2.2 .6 & $\begin{array}{l}\text { Написання підрозділів } 1.1-1.3 \\
\text { першого розділу дисертації }\end{array}$ & 0 & 31 & Пн 03.12.18 & $\begin{array}{l}\mathrm{Cp} \\
16.01 .19\end{array}$ & $5 ; 6$ & $\begin{array}{l}\text { Д[30\%] } \\
; Н \text { НК } 35 \\
\%]\end{array}$ \\
\hline 11 & 2.2 .7 & $\begin{array}{l}\text { Написання підрозділів 2.1-2.3 } \\
\text { другого розділу дисертації }\end{array}$ & 0 & 31 & Чт 17.01.19 & $\begin{array}{l}\text { Чт } \\
28.02 .19\end{array}$ & 10 & $\begin{array}{l}\text { Д[30\%] } \\
; Н \text { Н }[35 \\
\%]\end{array}$ \\
\hline 12 & 2.2 .8 & Міжсеместровий звіт & 0 & 10 & Пт 01.03.19 & $\begin{array}{l}\prod_{\mathrm{T}} \\
15.03 .19 \\
\end{array}$ & $\begin{array}{l}7 ; 8 ; 9 \\
; 11 \\
\end{array}$ & Д \\
\hline 13 & 2.3 & 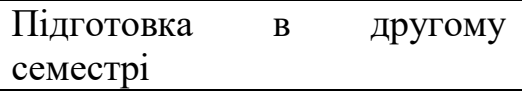 & 2250 & 117 & Пн 01.04.19 & $\begin{array}{l}\text { Пт } \\
13.09 .19\end{array}$ & & \\
\hline 14 & 2.3.1 & $\begin{array}{l}\text { Опрацювання } \\
\text { джітерел (a2) }\end{array}$ & 0 & 107 & Пн 01.04.19 & $\begin{array}{l}\Pi_{\mathrm{T}} \\
30.08 .19\end{array}$ & 12 & Д[10\%] \\
\hline 15 & 2.3 .2 & Публікація тез доповідей (b2) & 250 & 107 & Пн 01.04.19 & $\begin{array}{l}\text { Пт } \\
30.08 .19\end{array}$ & 12 & $\begin{array}{l}\text { Д[10\%] } \\
; Н К[10 \\
\%] ; П Т[ \\
250 Z]\end{array}$ \\
\hline 16 & 2.3 .3 & $\begin{array}{l}\text { Публікація наукових статей } \\
\text { (с2) }\end{array}$ & 2000 & 107 & Пн 01.04.19 & $\begin{array}{l}\text { Пт } \\
30.08 .19\end{array}$ & 12 & $\begin{array}{l}\text { Д[20\%]; } \\
\text { НК[20\% } \\
] ; П С[20 \\
00 Z]\end{array}$ \\
\hline
\end{tabular}


Закінчення таблиці 1

\begin{tabular}{|l|l|l|l|l|l|l|l|l|}
\hline $\mathbf{1}$ & $\mathbf{2}$ & $\mathbf{3}$ & $\mathbf{4}$ & $\mathbf{5}$ & $\mathbf{6}$ & $\mathbf{7}$ & $\mathbf{8}$ & $\mathbf{9}$ \\
\hline 17 & 2.3 .4 & $\begin{array}{l}\text { Написання підрозділів 3.1-3.3 } \\
\text { третього розділу дисертації }\end{array}$ & 0 & 54 & Пн 01.04.19 & $\begin{array}{l}\text { Пн } \\
17.06 .19\end{array}$ & $\begin{array}{l}\text { Д[30\%] } \\
; \text { НК[35 } \\
\%]\end{array}$ \\
\hline 18 & 2.3 .5 & $\begin{array}{l}\text { Написання підрозділів 4.1-4.3 } \\
\text { четвертого розділу дисертації }\end{array}$ & 0 & 53 & Вт 18.06 .19 & $\begin{array}{l}\text { Пт } \\
30.08 .19\end{array}$ & $\begin{array}{l}\text { Д[30\%] } \\
; \text { НК[35 } \\
\%]\end{array}$ \\
\hline 19 & 2.3 .6 & Річний звіт & 0 & 10 & Пн 02.09.19 & $\begin{array}{l}\text { Пт } \\
13.09 .19\end{array}$ & $\begin{array}{l}14 ; 1 \\
5 ; 16 ; \\
18\end{array}$ & Д \\
\hline 20 & 2.4 & $\begin{array}{l}\text { Закінчення першого року } \\
\text { підготовки }\end{array}$ & 0 & 0 & Пн 30.09.19 & $\begin{array}{l}\text { Пн } \\
30.09 .19\end{array}$ & 19 & \\
\hline $\begin{array}{l}\text { Примітка: Д - докторант, НК - науковий консультант, ВРУ - вчена рада університету, ПТ - } \\
\text { публікація тез, ПС - публікація статей; величини а1-а2, ь1-b2, с1-с2 визначає науковий } \\
\text { консультант. }\end{array}$ \\
\hline
\end{tabular}

Джерело: сформовано авторами.

Таблиия 2

Задачі проекту підготовки доктора наук протягом другого року

\begin{tabular}{|c|c|c|c|c|c|c|c|c|}
\hline $\begin{array}{l}\text { № } \\
\text { Ря } \\
- \\
\text { дк } \\
\mathbf{a} \\
\end{array}$ & СДР & Назва задачі & $\begin{array}{l}\text { Вит } \\
\text { ра- } \\
\text { ти, } \\
\text { грн }\end{array}$ & $\begin{array}{l}\text { Три- } \\
\text { ва- } \\
\text { ліст } \\
\text { ь, } \\
\text { днів }\end{array}$ & Початок & $\begin{array}{l}\text { Закінче } \\
\text { н-ня }\end{array}$ & $\begin{array}{l}\text { По- } \\
\text { пе- } \\
\text { ред- } \\
\text { ни- } \\
\text { ки }\end{array}$ & $\begin{array}{l}\text { Назви } \\
\text { ресурсі } \\
\text { в }\end{array}$ \\
\hline 1 & 2 & 3 & 4 & 5 & 6 & 7 & 8 & 9 \\
\hline 21 & 3 & Другий рік підготовки & 7750 & 255 & Вт 01.10 .19 & $\begin{array}{l}\text { Cp } \\
30.09 .20\end{array}$ & & \\
\hline 22 & 3.1 & $\begin{array}{l}\begin{array}{l}\text { Початок } \\
\text { підготовки }\end{array} \\
\text { другого }\end{array}$ & 0 & 0 & Вт 01.10.19 & $\begin{array}{l}\mathrm{BT} \\
01.10 .19\end{array}$ & 20 & \\
\hline 23 & 3.2 & $\begin{array}{lll}\begin{array}{l}\text { Підготовка } \\
\text { семестрі }\end{array} & \text { в } & \text { третьому } \\
\end{array}$ & 2250 & 115 & Вт 01.10.19 & $\begin{array}{l}\text { Пт } \\
13.03 .20 \\
\end{array}$ & & \\
\hline 24 & 3.2 .1 & $\begin{array}{l}\text { Опрацювання } \\
\text { джерел (a3) }\end{array}$ & 0 & 105 & Вт 01.10.19 & $\begin{array}{l}\text { Пт } \\
28.02 .20\end{array}$ & 22 & Д[5\%] \\
\hline 25 & 3.2 .2 & Публікація тез доповідей (b3) & 250 & 105 & Вт 01.10.19 & $\begin{array}{l}\text { Пт } \\
28.02 .20\end{array}$ & 22 & $\begin{array}{l}\text { Д[5\%]; } \\
\text { НК[5\%]; } \\
\text { ПТ }[250 \\
\text { Z] }\end{array}$ \\
\hline 26 & 3.2 .3 & $\begin{array}{l}\text { Публікація наукових статей } \\
\text { (c3) }\end{array}$ & 2000 & 105 & Вт 01.10 .19 & $\begin{array}{l}\text { Пт } \\
28.02 .20\end{array}$ & 22 & $\begin{array}{l}\text { Д[10\%]; } \\
\text { НК }[10 \% \\
] ; П С[20 \\
00 Z]\end{array}$ \\
\hline 27 & 3.2 .4 & $\begin{array}{l}\text { Написання підрозділів 5.1-5.3 } \\
\text { п’ятого розділу дисертації }\end{array}$ & 0 & 53 & Вт 01.10.19 & $\begin{array}{l}\Pi_{\mathrm{T}} \\
13.12 .19\end{array}$ & 22 & $\begin{array}{l}\text { Д[30\%]; } \\
\mathrm{HК}[35 \%\end{array}$ \\
\hline 28 & 3.2 .5 & $\begin{array}{l}\text { Попередній } \\
\text { результатів власних наукових } \\
\text { досягнень на кафедрі }\end{array}$ & 0 & 52 & Пн 16.12.19 & $\begin{array}{l}\text { Пт } \\
28.02 .20\end{array}$ & 27 & $\begin{array}{l}\text { Д[50\%]; } \\
\text { НК }[50 \%\end{array}$ \\
\hline 29 & 3.2 .6 & Міжсеместровий звіт & 0 & 10 & Пн 02.03.20 & $\begin{array}{l}\Pi_{\mathrm{T}} \\
13.03 .20\end{array}$ & $\begin{array}{l}24 ; 2 \\
5 ; 26 \\
; 28\end{array}$ & Д \\
\hline 30 & 3.3 & $\begin{array}{lcc}\begin{array}{l}\text { Підготовка } \\
\text { семестрі }\end{array} & \text { в } & \text { четвертому } \\
\end{array}$ & 5500 & 118 & Cp 01.04.20 & $\begin{array}{l}\text { BT } \\
15.09 .20\end{array}$ & & \\
\hline
\end{tabular}


РОЗДІЛ ІІІ. Економіка та управління підприсмствами.3, 2019

\begin{tabular}{|c|c|c|c|c|c|c|c|c|}
\hline \multicolumn{9}{|c|}{ Закінчення таблиці 2} \\
\hline 1 & 2 & 3 & 4 & 5 & 6 & 7 & 8 & 9 \\
\hline 31 & 3.3 .1 & $\begin{array}{l}\text { Опрацювання } \\
\text { джерел (a4) }\end{array}$ & 0 & 107 & $\mathrm{Cp} 01.04 .20$ & $\begin{array}{l}\text { Пн } \\
31.08 .2 \\
0\end{array}$ & 29 & Д[5\%] \\
\hline 32 & 3.3 .2 & Публікація тез доповідей (b4) & 250 & 107 & Cp 01.04.20 & $\begin{array}{l}\text { Пн } \\
31.08 .2 \\
0\end{array}$ & 29 & $\begin{array}{l}\text { Д[5\%];Н } \\
\text { К[5\%];П } \\
\text { Т[250Z] }\end{array}$ \\
\hline 33 & 3.3 .3 & $\begin{array}{l}\text { Публікація наукових статей } \\
\text { (c4) }\end{array}$ & 2000 & 107 & $\mathrm{Cp} 01.04 .20$ & $\begin{array}{l}\text { Пн } \\
31.08 .2 \\
0\end{array}$ & 29 & $\begin{array}{l}\text { Д[10\%]; } \\
\text { НК }[10 \% \\
] ; П С[20 \\
00 \text { ₹] }\end{array}$ \\
\hline 34 & 3.3 .4 & $\begin{array}{l}\text { Подання до спеціалізованої } \\
\text { вченої ради результатів } \\
\text { власних наукових досягнень }\end{array}$ & 3250 & 85 & Пн 04.05.20 & $\begin{array}{l}\text { Пн } \\
31.08 .2 \\
0\end{array}$ & 29 & $\begin{array}{l}\text { Д[80\%]; } \\
\text { НК[85\% } \\
\text { ];ПО[25 } \\
0 \text { 0Z];ПП[ } \\
\text { 1000Z]; } \\
\text { PA[1000 } \\
\text { Z];ТВ[1 } \\
\text { 000Z] }\end{array}$ \\
\hline 35 & 3.3 .5 & Річний звіт & 0 & 11 & Вт 01.09.20 & $\begin{array}{l}\mathrm{BT} \\
15.09 .2 \\
0 \\
\end{array}$ & $\begin{array}{l}31 ; 3 \\
2 ; 33 ; \\
34 \\
\end{array}$ & Д \\
\hline 36 & 3.4 & $\begin{array}{l}\text { Закінчення другого року } \\
\text { підготовки }\end{array}$ & 0 & 0 & Cp 30.09.20 & $\begin{array}{l}\text { Cp } \\
30.09 .2 \\
0\end{array}$ & 35 & \\
\hline 37 & 4 & Закінчення проекту & 0 & 0 & Cp 30.09.20 & $\begin{array}{l}\mathrm{Cp} \\
30.09 .2 \\
0\end{array}$ & 36 & \\
\hline & $\begin{array}{l}\text { пка: } \\
\text { публ } \\
\text { фера }\end{array}$ & $\begin{array}{l}\text { - докторант, НК - науковий к } \\
\text { ція оголошення про захист д } \\
\text { ТВ - транспортні витрат }\end{array}$ & $\begin{array}{l}\text { сул } \\
\text { ерта }\end{array}$ & T & $\begin{array}{l}\text { публікація } \\
\text { оліграфічн } \\
-\mathrm{a} 4, \mathrm{~b} 3-\mathrm{b} 4\end{array}$ & $\begin{array}{l}\text { ез, ПС- } \\
\text { послуги, } \\
\text { с3-с4 ви }\end{array}$ & $\begin{array}{l}\text { блі } \\
\text { А - }\end{array}$ & $\begin{array}{l}\text { я статей, } \\
\text { зсилання } \\
\text { гауковий }\end{array}$ \\
\hline
\end{tabular}

Щодо попереднього захисту результатів наукових досягнень на кафедрі та їх подання до спеціалізованої вченої ради, то тут він також повинен брати участь, зокрема готувати відгуки, виступати на засіданнях.

Слід зазначити, що в полі «Назви ресурсів» табл. 1-2 після назви трудового ресурсу (докторант, науковий консультант, вчена рада університету) в дужках відображено частку його зайнятості для конкретної задачі. Якщо зайнятість трудового ресурсу повна, відсотки (100) не відображаються.

Висновки. У межах цього дослідження здійснено теоретико-методичне обгрунтування процесу планування проекту підготовки доктора наук засобами Microsoft Office Project. Зокрема:

1. Обгрунтовано підготовку доктора наук як науковий проект.

2. Розроблено проект підготовки доктора наук засобами Microsoft Office Project.

Упровадження розробленого наукового проекту підготовки доктора наук у діяльності 3ВО (наукових установ) дозволить науковим консультантам i працівникам відділу докторантури оперативно й ефективно здійснювати процеси моніторингу й управління, зокрема визначати відповідність виконання докторантом проекту поставленим цілям, прийняття рішень про необхідність застосування коригувальних впливів, їх визначення та застосування.

Універсальність розробленого проекту полягає в тому, що його можна застосовувати в діяльності відділу докторантури будь якого ЗВО (наукової установи) України для управління 
підготовкою докторів наук з відповідними змінами тривалості задач, дат їх початку та закінчення, а також затрат на їх виконання.

Загалом, розроблений проект може слугувати основою для інших наукових проектів, як от підготовка доктора філософії, участь у держбюджетних темах тощо.

\section{Джерела та література}

1. Довгань Л. Є., Мохонько Г.А., Малик І. П. Управління проектами: навч. посіб. до вивчення дисципліни для магістрів галузі знань 07 «Управління та адміністрування» спеціальності 073 «Менеджмент» спеціалізації: «Менеджмент і бізнес-адміністрування», «Менеджмент міжнародних проектів», «Менеджмент інновацій», «Логістика». Київ: КПІ ім. Ігоря Сікорського, 2017. 420 с.

2. Статистична інформація «Вища освіта в Україні у 2018 році». URL: http://www.ukrstat.gov.ua/ (дата звернення: 10.05.2019).

3. Павліха Н. В., Долиняк Ю. О. Стратегічні напрями активізації розвитку регіональних ринків освітніх послуг в Україні. Економічний простір: зб. наук. праць. Дніпропетровськ, 2017. № 128. С. $214-223$.

4. Павліха Н. В., Цимбалюк І. О., Долиняк Ю. О. Особливості розвитку регіональних ринків освітніх послуг в Україні. Економіка ma суспільство. 2018. № $15 . \quad$ С. 540-544. URL: http://economyandsociety.in.ua/journal/15_ukr/83.pdf (дата звернення: 10.06.2019).

5. Бедрій Д. І. Експертний метод оцінки ризиків наукових проектів. Восточно-Европейский журнал nередовых технологий. 2013. Т. 1: Интегрированное стратегическое управление, управление проектами и программами развития предприятий и территорий. № 10(61). С. 66-68. URL: http://journals.uran.ua/eejet/article/view/6747/5978 (дата звернення: 10.05.2019).

6. Бедрій Д. І., Польшаков І. В. Бюджетування наукових проектів з урахуванням ризиків. ВосточноЕвропейский журнал передовых технологий. 2012. Т. 1: Интегрированное стратегическое управление, управление проектами и программами развития предприятий и территорий. № 12(55). C. 47-49. URL: http://journals.uran.ua/eejet/article/view/3626/3399 (дата звернення: 10.05.2019).

7. Holovko S. Doctoral Studies in the Homeland Higher Education: Experience and Prospects of the European Dimension. Proceedings of the National Aviation University. 2017. № 3(72). P. 142-150. Doi: 10.18372/2306-1472.72.12036.

8. Про затвердження Порядку підготовки здобувачів вищої освіти ступеня доктора філософії та доктора наук у закладах вищої освіти (наукових установах): Постанова КМУ від 23 берез. 2016 р. № 261. URL: http://zakon.rada.gov.ua/laws/show/261-2016-п (дата звернення: 10.05.2019).

9. Деякі питання стипендіального забезпечення: Постанова КМУ від 28 груд. 2016 р. № 1050. URL: https://www.kmu.gov.ua/ua/npas/249638784 (дата звернення: 10.05.2019).

\section{References}

1. Dovhan, L. Ye., Mokhonko, H. A. \& Malyk, I. P. (2017). Upravlinnia proektamy [Project management]. Kyiv: KPI im. Ihoria Sikorskoho [in Ukrainian].

2. Statystychna informatsiia «Vyshcha osvita v Ukraini u 2018 rotsi» [Statistical information «Higher education in Ukraine in 2018»]. ukrstat.gov.ua. Retrieved from http://www.ukrstat.gov.ua/ [in Ukrainian].

3. Pavlikha, N. V. \& Dolyniak, Yu. O. (2017). Stratehichni napriamy aktyvizatsii rozvytku rehionalnykh rynkiv osvitnikh posluh $\mathrm{v}$ Ukraini [Strategic directions of activation of development of regional markets of educational services in Ukraine]. Ekonomichnyi prostir: zb. nauk. prats. - Economic Space: a collection of scientific works. Dnipropetrovsk, № 128, 214-223 [in Ukrainian].

4. Pavlikha, N. V., Tsymbaliuk, I. O. \& Dolyniak Yu. O. (2018). Osoblyvosti rozvytku rehionalnykh rynkiv osvitnikh posluh $\mathrm{v}$ Ukraini [Features of the development of regional markets of educational services in Ukraine]. Ekonomika ta suspilstvo - Economics and Society, № 15, 540-544. Retrieved from http://economyandsociety.in.ua/journal/15_ukr/83.pdf [in Ukrainian].

5. Bedrii, D. I. (2013). Ekspertnyi metod otsinky ryzykiv naukovykh proektiv [Expert method of risk assessment of scientific projects]. Vostochno-Evropejskij zhurnal peredovyh tekhnologij - Eastern-European Journal of Enterprise Technologies, 1: Integrirovannoe strategicheskoe upravlenie, upravlenie proektami $i$ programmami razvitiya predpriyatij i territorij - 1: Integrated strategic management, project and programs management of development of enterprises and territories, № 10(61), 66-68. Retrieved from http://journals.uran.ua/eejet/article/view/6747/5978 [in Ukrainian].

6. Bedrii, D. I. \& Polshakov, I. V. (2012). Biudzhetuvannia naukovykh proektiv z urakhuvanniam ryzykiv [Budgeting of scientific projects taking into account risks]. Vostochno-Evropejskij zhurnal peredovyh tekhnologij - Eastern-European Journal of Enterprise Technologies, 1: Integrirovannoe strategicheskoe 
upravlenie, upravlenie proektami i programmami razvitiya predpriyatij i territorij - 1: Integrated strategic management, project and programs management of development of enterprises and territories, № 12(55), 4749. Retrieved from http://journals.uran.ua/eejet/article/view/3626/3399 [in Ukrainian].

7. Holovko, S. (2017). Doctoral Studies in the Homeland Higher Education: Experience and Prospects of the European Dimension. Proceedings of the National Aviation University, 3(72), 142-150. Doi: 10.18372/23061472.72.12036 [in English].

8. Pro zatverdzhennia Poriadku pidhotovky zdobuvachiv vyshchoi osvity stupenia doktora filosofii ta doktora nauk u zakladakh vyshchoi osvity (naukovykh ustanovakh): Postanova KMU vid 23 berez. 2016 r. № 261 [On Approval of the Procedure for Preparing Higher Education Applicants of Degree of Doctor of Philosophy and Doctor of Science in Higher Education Institutions (Academic Institutions): Resolution of the Cabinet of Ministers of Ukraine from March 23 2016, № 261]. Retrieved from http://zakon.rada.gov.ua/laws/show/2612016-п [in Ukrainian].

9. Deiaki pytannia stypendialnoho zabezpechennia: Postanova KMU vid 28 hrud. 2016 r. № 1050 [Some issues of scholarship support: Resolution of the Cabinet of Ministers of Ukraine from December 28 2016, № 1050]. Retrieved from https://www.kmu.gov.ua/ua/npas/249638784 [in Ukrainian].

Стаття надійшла до редакції 25.06.2019 р.

УДК 334.7-049.5:502.1

Черчик Лариса, доктор економічних наук, професор, Східноєвропейський національний університет імені Лесі Українки, кафедра менеджменту, м. Луцьк; ORCID ID 0000-0002-3901-216X e-mail: larysacherchyk@gmail.com

https://doi.org/10.29038/2411-4014-2019-03-71-80

\section{СТРУКТУРА СОЦІОЕКОЛОГОЕКОНОМІЧНОЇ БЕЗПЕКИ ПІДПРИЕМСТВА}

У статті розглянуто існуючі підходи до визначення структури та сутності складових соціальної, екологічної та економічної безпеки. Наукова новизна дослідження полягає у розвитку теорії безпеки підприємства, удосконаленні підходів до визначення сутності та змістовного наповнення складових соціоекологоекономічної безпеки підприємства на основі ресурсного та функціонального підходу 3 використанням методу ієрархічної декомпозиції (перший рівень декомпозиції - виділення соціальної, екологічної та економічної безпеки підприємства; другий - розгляд складових соціальної, екологічної та економічної безпеки підприємства; третій рівень - визначення змістовного наповнення окремих підсистем соціальної, екологічної та економічної безпеки підприємства). Застосовані підходи акцентують увагу на найважливіших ресурсах та видах діяльності підприємства, що дає можливість отримати інформацію для прийняття обгрунтованих управлінських рішень, визначити цільові установки розвитку підприємства на стратегічну перспективу з позицій забезпечення соціоекологоекономічної безпеки загалом, тактичного та операційного рівня - в контексті ії окремих складових.

Ключові слова: безпека, соціоекологоекономічна безпека підприємства, структуризація соціоекологоекономічної безпеки підприємства.

Черчик Лариса, доктор экономических наук, профессор, Восточноевропейский национальный университет имени Леси Украинки, кафедра менеджмента, г. Луцк

\section{СТРУКТУРА СОЦИОЕКОЛОГОЕКОНОМИЧНОИ БЕЗОПАСНОСТИ ПРЕДПРИЯТИЯ}

